\title{
The status of Drymobius reissii Peters, 1868 (Serpentes, Colubridae)
}

Fernanda M. D’Agostini' ${ }^{1,2}$, Thales De Lema ${ }^{1}$, Síria L. B. Ribeiro ${ }^{1}$

${ }^{1}$ Laboratório de Herpetologia, Museu de Ciências e Tecnologia da Pontifícia Universidade Católica do Rio Grande do Sul, Campus Partenon, Av. Ipiranga 6681, Caixa Postal 1429, 90619-900, Porto Alegre, RS, Brazil. E-mail: dagostin@pucrs.br.

2 Faculdade de Ciências Biológicas, Universidade Regional Integrada do Alto Uruguai e das Missões, Campus Santo Ângelo, Rua Universidade das Missões, 464, 98802-470, Santo Ângelo, RS, Brazil.

Keywords: Serpentes, Colubridae, Drymobius reissii, Mastigodryas pulchriceps, synonymy, revalidation.

The name Drymobius reissii was forgotten and one of us (FMDA) is revising the genus Drymobius and examined the holotype of that species discovering its true identification. Peters (1868) described as Herpetodryas (Drymobius) reissii with a specimen from Guayaquil, Ecuador, and deposited in the Zoologisches Museum zu Berlin (ZMB 4507). The original description provided data on head shields, number of dorsal scales, ventral scales, subcaudal scales and coloration. In the same year, Cope (1868) described another species calling Masticophis pulchriceps with holotype from Quito, Ecuador, also based on head plates, number of scales and coloration. This specimen was deposited at the National Museum of Natural History of Washington (USNM 6704). Stuart (1941) described the genus Dryadophis allocating the Cope's species in it (Dryadophis pulchriceps). Peters and Orejas-Miranda (1970)

Received 26 May 2003.

Accepted 10 November2003.

Distributed 19 December 2003. synonymyzed previously Dryadophis with Mastigodryas Amaral 1935 using Mastigodryas pulchriceps. Vanzolini (1977) discovered the Peters's name, and revalidated it correcting the original presentation as Drymobius reissii. Bauer et al. (1995), reviewing the herpetological work of Wilhelm Peters, provided the number of the holotype and commented that the species was not cited in the Catalogue of Neotropical Squamata of Peters and Orejas-Miranda (1970).

We examined the holotype of Drymobius reissii, which is a young female with the number of dorsal scale rows as 17-19-17-15 counting at neck, middle, posterior, and precloacal regions, respectively, and to determine the scale reduction formula according to Dowling (1951); pre and postoculars $1+2$; supralabials 9 , fourth to sixth entering the orbit; infralabials 10 , first to sixth contacting anterior chin shields; temporals $2+2$; preventrals 2 ; ventrals 186 ; subcaudals 110; anal plate divided. The measurements taken are (mm): head length 14.8; snout-vent length 267.0; tail length 100.0; snout length 4.4; diameter of the orbit 3.2. The dorsal pattern presents 20 dark blotches on trunk and 14 on tail (Figure 1). 


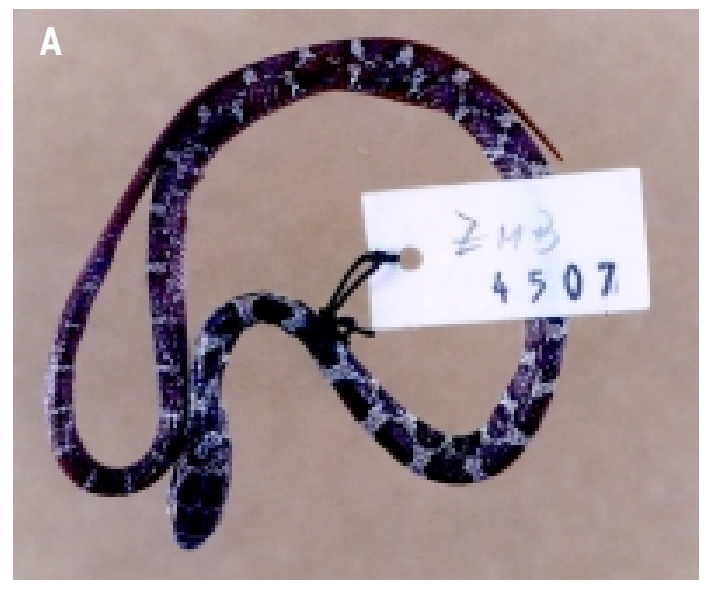

The reduction dorsal scale rows formula is:

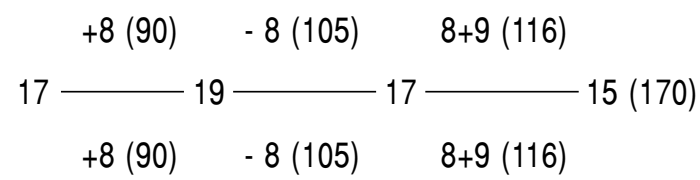

The data of holotype of Drymobius reissii compared with the description of Mastigodryas pulchriceps Cope 1868, together the Dryadophis revision of Stuart (1941), show the identity of the two names. The presentation of the description of the two names was September by Peters, and March by Cope, so the Cope's name has priority and, therefore, Drymobius reissii Peters 1868 is a junior synonym of Mastigodryas pulchriceps (Cope 1868).

\section{Acknowledgements}

We thank Rainer Günther (Zoologisches Museum of Berlin) for loan of specimen, Klaus Hilbert for translation of German text, Hobart H. Smith for help with bibliography. The present contribution received financial support from Coordenadoria de Aperfeiçoamento de Pessoal de Ensino Superior (CAPES), Distrito Federal, Brazil.

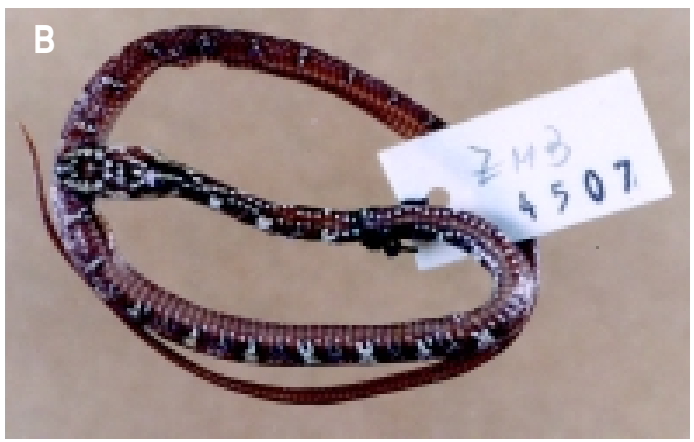

Figure 1 - Drymobius reissii holotype (ZMB 4507) in (A) dorsal and (B) ventral view.

\section{References}

Bauer, A. A., R. Günther and M. Klipfel. 1995. The Herpetological Contributions of Wilhelm C. H. Peters (1815-1883). SSAR. 714 pp.

Cope, E. D. 1868. An examination of the Reptilia and Batrachia obtained by the Orton Expedition to Ecuador and the Upper Amazon, with notes on other species. Proceedings of the Academy of Natural Sciences of Philadelphia 20: 96-119.

Dowling, H. G. 1951. A proposed method of expressing scale reductions in snakes. Copeia 1951: 131-134.

Peters, J. A. and B. Orejas-Miranda. 1970. Catalogue of the Neotropical Squamata. Part I. Snakes. Bulletin of the United States National Museum 297: 1-347.

Peters, W. 1868. Über einige neue oder weniger bekannte Amphibien. Monatsberichte der Königlich Preussischen Akademie der Wissenschaften zu Berlin 1868: 640-642.

Stuart, L. C. 1941. Studies of Neotropical Colubrinae. VIII. A revision of the genus Dryadophis Stuart, 1939. Miscellaneous Publications of the Museum of Zoology, University of Michigan 49: 1-106.

Vanzolini, P. E. 1977. An Annotated Bibliography of the Land and Fresh-Water Reptiles of South America (1758-1975). São Paulo. Museu de Zoologia da USP. 2 vols. 